\title{
The Feasibility of Interactive Multimedia Validation Data Results on Folk Poetry Texts Learning in MTS Nurul Amaliyah Tanjung Morawa
}

\author{
Nurul Silfi Dhawirta ${ }^{1}$, Syahnan Daulay ${ }^{2}$, Khairil Ansari ${ }^{2}$ \\ ${ }^{1}$ Master Student in Universitas Negeri Medan (Unimed), Medan, Indonesia \\ ${ }^{2}$ Lecturer in Universitas Negeri Medan (Unimed), Medan, Indonesia \\ nsilfid@gmail.com
}

\begin{abstract}
This study is aimed to know the feasibility of interactive multimedia validation data results on folk poetry texts learning. The development of interactive multimedia is focused on folk poetry text material. The students are expected to learn independently through interactive multimedia that has been adjusted by the developer. The research and development population is VII grade students of MTS Nurul Amaliyah Tanjung Morawa. The research was using the $4 D$ method, which involves four stages of research: define, design, development, and disseminate. The product of this research results in the form of interactive multimedia development of folk poetry texts is Adobe Flash CS5 media. The results shows that the feasibility of the media and material scored an average of $88.8 \%$ with the criteria of "good" and $86.4 \%$ with the criteria of "good" in the development of interactive multimedia on folk poetry text learning.
\end{abstract}

Keywords: feasibility; interactive multimedia; folk poetry text.

\section{Introduction}

The source of learning in essence must be adjusted through the text-based 2013 curriculum content considered important because in its application students must be able to produce text in each lesson.

As explained by Tomlinson (2014: 37) the selection of materials involves matching the given materials against the context in which they are going to be used and the needs and interests of the teachers and learners who work within it, to find the best possible fit between them. This calls for major strategic decisions based on informed judgment and professional experience, forcing teachers to identify their priorities.

Material selection involves matching the materials given to the context in which they will be used according to the needs and interests of the teacher and the students who work in them, to find the best fit between the two. This requires major strategic decisions based on assessment and assessment of professional experience, forcing teachers to identify their priorities.

One of the texts is the folk poetry text that contained in KD 3.9 Identifying information (messages, rhymes, and choice of words) of folk poetry (poem, poetry, and local folk poetry forms) that are read and heard. 4.9 Summing up the contents of folk poetry (poem, poetry, and local folk poetry forms) presented in written form. 3.10 Examine the structure and language of folk poetry (poem, poetry, and local folk poetry forms) that are read and heard. 4.10 Expressing ideas, feelings, and messages in the form of folk poetry verbally and written by paying attention to the structure, rhyme and use of language.

Based on observations of researchers in MTS Nurul Amaliyah Tanjung Morawa, it was concluded that the skills for study the folk poetry texts of VII grade students of MTS Nurul Amaliyah Tanjung Morawa was still low. This is known from the scores obtained by the average student who has not met the Minimum Mastery Criteria (KKM) set by this school. The KKM standard set is 75 . The reality on the ground is that only $20 \%$ of students are able to achieve the KKM score. This is supported by the teacher's presentation in MTS Nurul 
Amaliyah Tanjung Morawa with Mrs. Khairi S.Pd and Mrs. Sri Wati Ningsih S.Pd, the low of folk poetry texts learning skills on students is seen from students' difficulties in terms of determining the structure and effective sentences in folk poetry texts essays.

This is because students do not understand the concept of folk poetry texts and students do not know the elements that build folk poetry texts, so learning outcomes of folk poetry texts are still low. Low student learning outcomes are also known from the uselessness of information technology in MTS Nurul Amaliyah Tanjung Morawa. This is evidenced from the observations of the researcher when they came out of the field, that learning in MTS Nurul Amaliyah Tanjung Morawa only uses printed media based learning media. The use of learning media in accordance with technological developments using computers has been done but in its development has not been implemented by the teacher. The empowerment of information technology is still merely making learning appearances through Power Point slides.

In this study, the development of interactive multimedia is focused on folk poetry text material. Here students are expected to learn independently through interactive multimedia that has been adjusted by the developer. The development of interactive multimedia in the folk poetry text is very important as a refinement in previous studies. Research related to the development of writing folk poetry texts has been carried out by Astriana. Development of Folk Poetry Learning Media Based on Macromedia Flash in to Students Class VII SMP Negeri 18 Medan Academic Year 2017/2018. Thesis: Education Language and Sastra Indonesia. Master Student at State University of Medan. 2018.

\section{Review of Literature}

\subsection{Interactive Multimedia}

Along with the development of information technology, formed a media that can combine various elements (text, images, animation, sound, and video) or better known as multimedia. Multimedia comes from multi words and media. Multi comes from Latin, which is nouns, which means many or various kinds. The word media comes from Latin which is a medium which means an intermediary or something used to deliver, deliver, or carry something. Vuagan (in Susilo 2017: 162) Multimedia is a combination of text, graphics, art, sound, animation, video which are interrelated elements. When it can follow the user's wishes, display multimedia projects and can control what and when elements are submitted, then that is what is called interactive multimedia. Jacob (in Susilo 2017: 162) says that interactive creates two-way or more user relationships. Interactive can increase creativity and the occurrence of feedback on what is entered by the user so that learning can be two or more directions if assisted by other media. Philip (in Susilo 2017: 162) defines interactive multimedia as a phrase that describes a new wave of computer software, especially related to the information section.

This multimedia component is marked by the presence of text, images, sound, animation, and video. Some or all of its components are organized into coherent programs. The interactive component refers to the process of empowering users to control the environment usually with a computer. With interactivity, users can engage in navigation content and in the communication process. Daryanto (2013: 52) Multimedia can be interpreted as multimedia used in the learning process, in other words it functions to channel messages (knowledge, skills and attitudes) and can stimulate student choices, feelings, concerns and wishes so that the learning process intentionally occurs, aims and controlled. 


\subsection{Adobe Flash CS5}

Technology has given find the software that can used to develop multimedia learning, such as Microsoft Office Power Point, Corel Presentation, Macromedia Flash or Adobe flash, Director MX. Multimedia development using Macromedia Flash software as a substitute for multimedia presentations that were previously more popular using Microsoft Office Power Point is considered to be more effective, because flash is one of the highly reliable animation creation programs. Daryanto (2005: 9) the reliability of flash compared to other programs is in terms of the file size of the small animation results.

\subsection{Folk Poetry Texts}

There are three forms of literary works, namely prose, poetry and drama. Poetry is the earliest written literary work written by humans. Alfiah (in Yuni 2016: 29) Poetry is a literary work with a language that is condensed, shortened, and given a rhythm with a unified sound and choice of words that are decorative or imaginative. Meanwhile, according to Rahmawati (2010: 1) "Literature can be divided into written literature and oral literature". Written literature is writing folk poetry. Folk poetry is a national cultural heritage that must be maintained. Folk poetry is one genre of oral folklore. Danandjaja (2007: 46). Folk poetry has a meaning as a certain form of people's literature, usually consisting of sentence series, some are based on spells, short syllables, weak sound pressure, or only based on rhythm.

Folk poetry is also called an old poetry. According to Damayanti (2013: 73) "Old poetry is a form of writing that is bound by rhyme, rhythm, or the number of lines and is marked by solid language". Meanwhile according to Sutana, et al (2015: 17) old poetry is a literary work that developed before there was influence from outside culture, and before the 20 'n generation or Balai Pustaka. Old poetry is poetry that has not been influenced by outside cultures. According to Pradopo (2002: 14) old poetry is poetry that is still bound by rules. Old poetry rules such as the number of words contained in 1 line, the number of lines contained in 1 stanza, poetry or rhymes, many syllables in each line, and rhythm ".

\subsection{Interactive Multimedia Schemes of Writing the Folk Poetry Texts}

In interactive multimedia that will be designed interactive multimedia schemes will contain components of writing poetry texts that is high comprehension competence, critical thinking, collaboration and communication as well as critical thinking components that are integrated with language skills, which in its application invites students to read through reading high-level understanding of this matter aims so that students are better able to interpret the information of folk poetry in the interactive multimedia in accordance with the speed and level of ability to understand one by one student.

Learning to write is a process of expressing ideas or thoughts in written form. Writing can be defined through various points of view. In the simplest point of view, writing can be interpreted as a process of producing sound symbols. This kind of understanding of writing is known as beginning writing. At a later stage writing can be more complex. Writing is basically the process of expressing ideas and ideas in written language.

In line with that, Soebachman (2014: 27) argues that writing is our communication media with others. A media to convey what we want, spread what we think, and invite others and lead them to participate in thinking and developing. Soebachman (2014: 85) also argues that writing is a process of giving birth to writings that contain ideas. This opinion is in line with Akhadiah (in Syamsuyurnita, 2012: 1) views writing as a language communication activity that uses 
writing as its medium. Writing as a thought process means that before and or after writing ideas and feelings in writing, it requires the involvement of the thought process.

\section{Research Method}

This research was conducted in MTS Nurul Amaliyah Tanjung Morawa of 2018/2019 learning year. The implementation of this research in the form of learning activities tailored to the educational calendar.

The research and development population is VII grade students of MTS Nurul Amaliyah Tanjung Morawa. To see the effectiveness of the products developed, the researchers only took samples using cluster sampling techniques. Researchers took a sample of 32 students from Class VII-1.

Table 1. Questionnaire Validation and Assessment of Learning Design Experts

\begin{tabular}{|c|c|c|c|}
\hline $\begin{array}{c}\text { Sub } \\
\text { Component }\end{array}$ & Rating Indicator & Respondent & Respondent \\
\hline \multirow[t]{7}{*}{$\begin{array}{l}\text { A. Initial } \\
\text { Design }\end{array}$} & $\begin{array}{l}\text { Appearance of layout elements on } \\
\text { the front background, behind neatly } \\
\text { and consistently }\end{array}$ & & \\
\hline & Interesting element colors & & \\
\hline & Showing a good center point of view & & \\
\hline & $\begin{array}{l}\text { The composition and size of layout } \\
\text { elements (title, author, illustration, } \\
\text { logo, etc.) are proportional } \\
\text { according to a predetermined } \\
\text { pattern }\end{array}$ & & \\
\hline & The letters used are easy to read & & \\
\hline & $\begin{array}{l}\text { The module title color contrasts with } \\
\text { the background color }\end{array}$ & & \\
\hline & \begin{tabular}{|lccc}
$\begin{array}{l}\text { Don't use too many font } \\
\text { combinations }\end{array}$ & & \\
\end{tabular} & & \\
\hline \multirow[t]{4}{*}{$\begin{array}{l}\text { B. Design } \\
\text { Content }\end{array}$} & $\begin{array}{l}\text { Layout elements are consistent } \\
\text { based on patterns }\end{array}$ & & \\
\hline & $\begin{array}{l}\text { Placement of the title of learning } \\
\text { activities }\end{array}$ & & \\
\hline & $\begin{array}{l}\text { Placement of illustrations and } \\
\text { captions appropriately }\end{array}$ & & \\
\hline & $\begin{array}{llr}\text { Placement of titles, } & \text { subtitles, } \\
\text { illustrations, and image } & \text { captions } \\
\text { does not interfere } & \text { with } \\
\text { understanding }\end{array}$ & & \\
\hline
\end{tabular}




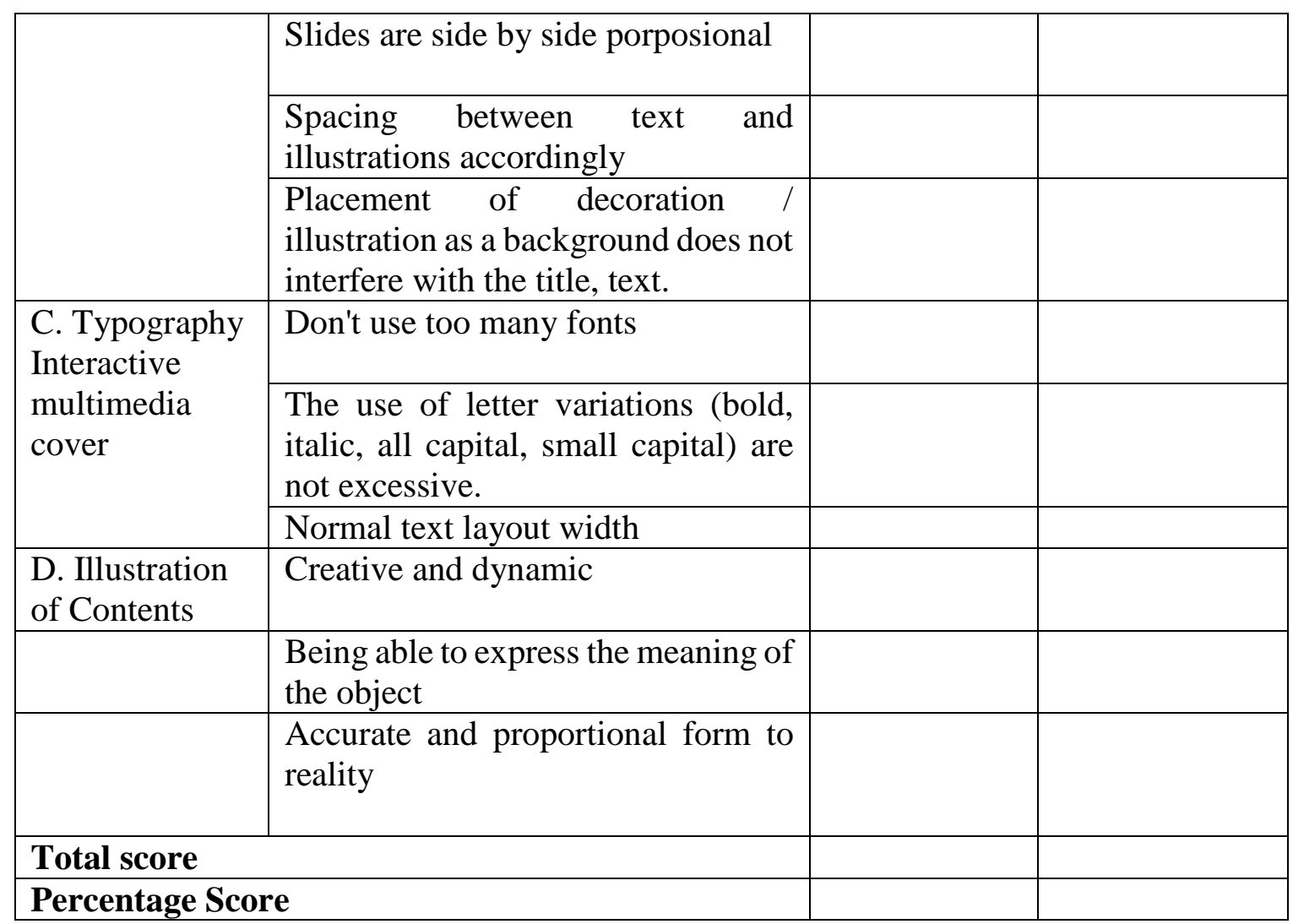

\section{Discussion}

\subsection{Research Results}

4.1.1 The Process of Interactive Multimedia Development

The research that has been implemented is research and development using the 4D method, which involves four stages of research: define, design, development, and disseminate.

The product of this research results in the form of interactive multimedia development of folk poetry texts is Adobe Flash CS5 media.

\section{1). Define Stage}

a. Requirements Analysis

Analysis of the needs of the results of the curriculum that conducted in VII grade of MTS Nurul Amaliyah Tanjung Morawa is the 2013 curriculum. The 2013 curriculum aims to encourage students to be able to do more, observe, ask questions, gather information, communicate and create. So, students are active in learning activities. This curriculum also emphasizes the importance of using interactive multimedia learning. At this stage the data was obtained about the conditions of learning folk poetry texts that were still experiencing difficulties, especially when given the task of writing folk poetry texts. Because of lack of understanding and examples of how to write folk poetry texts, so students tend to be difficult to determine the topic, it is difficult to express their ideas in writing folk poetry texts and less interesting learning media used by teachers when explain folk poetry texts.

In carrying out learning to write folk poetry text is not enough just by conventional methods, learning media is needed to support learning to write folk poetry texts. Therefore, it 
is necessary to develop a learning media in the form of interactive multimedia for folk poetry text material. Learning media developed in the form of interactive multimedia that can make students interested.

Based on the results of interviews about the development needs that is implemented on 2 teachers and 32 students. At first students are not familiar with interactive multimedia learning. Therefore, researchers provide an overview of the development needs carried out at the defining stage shown in tables 2 and 3 below:

Table 2. Data of Observation Results at the Define Stage conducted to students.

\begin{tabular}{|c|l|l|c|}
\hline No & \multicolumn{1}{|c|}{ A list of questions } & Answer & Frequency \\
\hline 1 & $\begin{array}{l}\text { Do you know about interactive multimedia } \\
\text { learning }\end{array}$ & Yes & 6 \\
No & 26 \\
\hline 2 & Do you use interactive multimedia learning & Yes & - \\
& \multicolumn{2}{|l}{ No } & 32 \\
\hline 3 & Do you need interactive multimedia learning & Yes & 30 \\
& No & 2 \\
\hline
\end{tabular}

Based on the results of the needs analysis for students, 6 students said they knew interactive multimedia learning, and 26 students did not know interactive multimedia learning. 32 students said they did not use interactive multimedia learning. 30 students need interactive multimedia learning and 2 students don't need to use interactive multimedia.

Table 3. Results Data at the Define Stage conducted to the teacher

\begin{tabular}{|c|l|l|c|}
\hline No & \multicolumn{1}{|c|}{ A list of questions } & Answer & Frequency \\
\hline 1 & $\begin{array}{l}\text { Do you know about interactive multimedia } \\
\text { learning }\end{array}$ & Yes & 1 \\
\hline 2 & No you use interactive multimedia learning & Yes & 1 \\
\hline 3 & Do you need interactive multimedia learning & No & - \\
\hline & Yes & 2 \\
\hline
\end{tabular}

Based on the results of the analysis of the need for teachers, 1 teacher knows interactive multimedia learning and 1 teacher does not know interactive multimedia learning. No teacher uses interactive multimedia learning. 2 teachers need interactive multimedia learning.

\section{b. Student Analysis}

Student's characteristics of VII grade MTS Nurul Amaliyah Tanjung Morawa in 2018/2019 learning year which includes cognitive development and background knowledge of students. Students at this age still need stimulation (invitation) to start something or real illustrations in learning to write folk poetry texts. Including matters related to the students' daily experiences. Experience is the best teacher, so the saying goes. This expression means that experience can be used as learning material about various life values.

Based on the results of the needs analysis interview, it was found that the students' experience of writing folk poetry texts using conventional methods was less interesting. 32 students are not familiar with interactive multimedia learning and 30 students need interactive multimedia learning to write folk poetry texts. 
The development stage aims to produce revised products based on expert input. At this stage the data collection was carried out in the form of validation of the development of interactive multimedia with the application of adobe flash CS5 shaped products writing folk poetry texts of students in MTS Nurul Amaliyah Tanjung Morawa. The assessment of feasibility of the development is seen from the feasibility of teaching materials and the feasibility of learning design. This validation data was obtained by distributing questionnaires to learning material experts and learning design experts.

Drafts generated by expert validation. Validation of experts is carried out covering all devices developed. Tools in the form of interactive multimedia and validation material in the form of corrections, criticisms and suggestions are used as a basis for making revisions and improvements to the learning tools. The revised learning tool is based on input from Draft validators.

Validation of the learning design is carried out by lecturers of the Department of Basic Education Medan State University who are competent in this field, namely Dr. Daulat Saragi, M.Hum, and Dr. Surya Masniari Hutagalung, M.Hum from a German study program lecturer from Medan State University. The assessment is conducted to determine the feasibility of a learning media, especially on a design. The assessment is also done to be able to make the appearance of an interesting digital learning media to be studied. Data from design validation can be seen in the following table.

Table 4. Data of Validation of Interactive Multimedia Design Results by Design Experts

\begin{tabular}{|c|c|c|c|}
\hline Sub Component & Rating Indicator & Respondent & Respondent \\
\hline \multirow[t]{7}{*}{ A. Initial Design } & $\begin{array}{l}\text { Appearance of layout elements on the } \\
\text { front background, behind neatly and } \\
\text { consistently }\end{array}$ & 4 & 4 \\
\hline & Interesting element colors & 3 & 4 \\
\hline & Showing a good center point of view & 3 & 4 \\
\hline & $\begin{array}{l}\text { The composition and size of layout } \\
\text { elements (title, author, illustration, } \\
\text { logo, etc.) are proportional according } \\
\text { to a predetermined pattern }\end{array}$ & 3 & 3 \\
\hline & The letters used are easy to read & 4 & 4 \\
\hline & $\begin{array}{l}\text { The module title color contrasts with } \\
\text { the background color }\end{array}$ & 3 & 3 \\
\hline & Don't use too many font combinations & 4 & 4 \\
\hline \multirow[t]{5}{*}{$\begin{array}{l}\text { B. Design } \\
\text { Content }\end{array}$} & $\begin{array}{l}\text { Layout layout elements are consistent } \\
\text { based on patterns }\end{array}$ & 4 & 4 \\
\hline & $\begin{array}{l}\text { Placement of the title of learning } \\
\text { activities }\end{array}$ & 4 & 4 \\
\hline & $\begin{array}{l}\text { Placement of illustrations and } \\
\text { captions appropriately }\end{array}$ & 3 & 3 \\
\hline & $\begin{array}{l}\text { Placement of titles, subtitles, } \\
\text { illustrations, and image captions does } \\
\text { not interfere with understanding }\end{array}$ & 4 & 3 \\
\hline & Slides are side by side porposional & 4 & 4 \\
\hline
\end{tabular}




\begin{tabular}{|c|c|c|c|}
\hline & $\begin{array}{l}\text { Spacing between text and illustrations } \\
\text { accordingly }\end{array}$ & 4 & 3 \\
\hline & $\begin{array}{l}\text { Placement of decoration / illustration } \\
\text { as a background does not interfere } \\
\text { with the title, text. }\end{array}$ & 4 & 3 \\
\hline \multirow{3}{*}{$\begin{array}{l}\text { C. Typography } \\
\text { Interactive } \\
\text { multimedia } \\
\text { cover }\end{array}$} & Don't use too many fonts & 4 & 4 \\
\hline & $\begin{array}{l}\text { The use of letter variations (bold, } \\
\text { italic, all capital, small capital) are not } \\
\text { excessive. }\end{array}$ & 3 & 4 \\
\hline & Normal text layout width & 3 & 3 \\
\hline \multirow[t]{3}{*}{$\begin{array}{l}\text { D. Illustration of } \\
\text { Contents }\end{array}$} & Creative and dynamic & 3 & 3 \\
\hline & $\begin{array}{l}\text { Being able to express the meaning of } \\
\text { the object }\end{array}$ & 4 & 4 \\
\hline & $\begin{array}{l}\text { Accurate and proportional form to } \\
\text { reality }\end{array}$ & 3 & 4 \\
\hline \multicolumn{2}{|l|}{ Total score } & 71 & 72 \\
\hline \multicolumn{2}{|l|}{ Score Percentage } & $\mathbf{8 8 , 7 5 \%}$ & $90 \%$ \\
\hline
\end{tabular}

The results of the validation carried out by the learning design expert as the first validator to the design of the product developed were obtained with a total score of 71 with a percentage of $88.75 \%$ with Good criteria. The second validator of the developed design was obtained with a total score of 72 with a percentage of $90 \%$ with criteria is Very Good. The comments in the form of suggestions for improvement given by the first design expert is generally fulfilling the requirements of a medium for good learning and easy for students to understand and need different color emphasis on each message to be conveyed. The second design expert comment is to add pictures to support the attractiveness of learning media

Validation is also given to material experts to see the feasibility of the material in accordance with the development of instructional media designed. The validation was conducted by a lecturer in Applied Linguistics in English (LTBI) who was competent in this field, namely Prof. Amrin Saragih, MA, Ph.D and Dr. Malan Lubis, M.Hum from Indonesian Language and Literature study program lecturer from Medan State University. The results provided by material experts can be seen in the following table 3 .

Table 5. Data of Validation Learning Materials Results by Material Experts

\begin{tabular}{|l|l|c|c|}
\hline \multicolumn{2}{|c|}{ I. Content Feasibility } & Respodent & Respondent \\
\hline Sub Component & \multicolumn{1}{|c|}{ Rating Indicator } & 4 \\
\hline $\begin{array}{l}\text { A. Conformity and } \\
\text { Depth of concept } \\
\text { with K13 }\end{array}$ & $\begin{array}{l}\text { Completeness of the text material of } \\
\text { the People's Poetry (Structure and } \\
\text { linguistic characteristics) }\end{array}$ & 3 & 4 \\
\cline { 2 - 4 } & $\begin{array}{l}\text { Material freedom and conformity } \\
\text { with K13 }\end{array}$ & 3 & 3 \\
\hline $\begin{array}{l}\text { B. Material } \\
\text { Accuracy }\end{array}$ & $\begin{array}{l}\text { The accuracy of the concepts and } \\
\text { definitions of the Folk Poetry texts }\end{array}$ & 4 & 3 \\
\cline { 2 - 4 } & The accuracy of facts and data & 3 & 4 \\
\hline
\end{tabular}




\begin{tabular}{|c|c|c|c|}
\hline & The accuracy of examples and cases & 3 & 3 \\
\hline & $\begin{array}{l}\text { The accuracy of terms, pictures and } \\
\text { symbols }\end{array}$ & 4 & 3 \\
\hline & The accuracy of library references & 4 & 3 \\
\hline \multirow[t]{4}{*}{$\begin{array}{l}\text { C. Learning } \\
\text { Support Materials }\end{array}$} & $\begin{array}{l}\text { The suitability of the material with } \\
\text { the learning process }\end{array}$ & 4 & 3 \\
\hline & $\begin{array}{l}\text { Displays the topic of events in the } \\
\text { Sumatra region }\end{array}$ & 3 & 4 \\
\hline & $\begin{array}{l}\text { Pictures, diagrams and illustrations } \\
\text { in everyday life }\end{array}$ & 3 & 4 \\
\hline & Literacy updates & 3 & 3 \\
\hline \multicolumn{4}{|c|}{ II. Feasibility of Learning Presentation } \\
\hline Sub Component & Rating Indicator & Respodent & Respondent \\
\hline \multirow[t]{4}{*}{$\begin{array}{l}\text { A. Presentation } \\
\text { Techniques }\end{array}$} & $\begin{array}{l}\text { Consistent systematic offerings in } \\
\text { learning activities }\end{array}$ & 3 & 4 \\
\hline & Conceptual noise & 4 & 4 \\
\hline & Material wrinkles & 3 & 4 \\
\hline & $\begin{array}{l}\text { The wrangling of the language in } \\
\text { which the material is presented }\end{array}$ & 4 & 4 \\
\hline \multirow{3}{*}{$\begin{array}{l}\text { B. Learning } \\
\text { Presentation }\end{array}$} & Student involvement & 3 & 4 \\
\hline & Student-centered & 3 & 4 \\
\hline & $\begin{array}{l}\text { Stimulate students' ability to solve } \\
\text { problems through the media }\end{array}$ & 4 & 3 \\
\hline \multirow{5}{*}{$\begin{array}{l}\text { C. Completeness of } \\
\text { Presentation }\end{array}$} & Introduction and table of contents & 4 & 4 \\
\hline & $\begin{array}{l}\text { Questions and practice answer keys } \\
\text { at the end of each learning activity }\end{array}$ & 4 & 4 \\
\hline & Glossary and bibliography & 3 & 4 \\
\hline & $\begin{array}{l}\text { Examples of questions in each } \\
\text { learning activity }\end{array}$ & 3 & 4 \\
\hline & Summary & 3 & 4 \\
\hline \multicolumn{4}{|c|}{ III. Interactive Multimedia Aspects } \\
\hline Sub Component & Rating Indicator & Respodent & Respondent \\
\hline \multirow[t]{3}{*}{ A. Perception } & Media accuracy & 3 & 4 \\
\hline & Language effectiveness & 4 & 3 \\
\hline & Sentence set & 3 & 3 \\
\hline \multirow[t]{3}{*}{ B. Strategy } & Provision of animation & 3 & 4 \\
\hline & Graphic Provisions & 3 & 4 \\
\hline & Image Provisions & 4 & 4 \\
\hline \multicolumn{4}{|c|}{ IV. Aspects of Language Assessment } \\
\hline Sub Component & Rating Indicator & Respodent & Respondent \\
\hline \multirow[t]{3}{*}{ A. Communicative } & Provision of language use & 4 & 4 \\
\hline & Spelling Resolution & 3 & 4 \\
\hline & Stance punctuation & 4 & 4 \\
\hline $\begin{array}{l}\text { B. Conformity with } \\
\text { the Level of }\end{array}$ & $\begin{array}{l}\text { Conformity with the level of } \\
\text { emotional development of students }\end{array}$ & 3 & 3 \\
\hline
\end{tabular}




\begin{tabular}{|l|l|c|c|}
\hline $\begin{array}{l}\text { Student } \\
\text { Development }\end{array}$ & $\begin{array}{l}\text { Suitability of intellectual develop- } \\
\text { ment of students }\end{array}$ & 3 & 3 \\
\hline $\begin{array}{l}\text { C. Corruption and } \\
\begin{array}{l}\text { Alignment of } \\
\text { the Mind Path }\end{array}\end{array}$ & $\begin{array}{l}\text { Chaos and cohesiveness between } \\
\text { learning activities }\end{array}$ & 3 & 3 \\
\cline { 2 - 4 } & $\begin{array}{l}\text { Aging and cohesiveness between } \\
\text { sentences between paragraphs }\end{array}$ & 3 & 3 \\
\hline \multirow{2}{*}{$\begin{array}{l}\text { D. Use of Terms, } \\
\text { Images and } \\
\text { Symbols }\end{array}$} & Consistent using the term & 3 & 4 \\
\cline { 2 - 4 } & Consistent using the symbols & 4 & 4 \\
\hline \multicolumn{2}{|l|}{ Total score } & $\mathbf{8 6 , 1 8}$ & $\mathbf{9 3 , 4 2 \%}$ \\
\hline \multicolumn{2}{|l|}{ Percentage Obtained Score } &
\end{tabular}

The results of the validation carried out by learning material experts as the first validator for the product design developed obtained a score of 131 and a percentage of $86.18 \% \%$ with Good criteria. The second validator obtained a score of 142 and a percentage of $93.42 \%$ with Very Good. Comments in the form of suggestions for improvement were given by the first material expert. In general, the material was well reviewed in terms of language, but it was necessary to add the examples of poem, poetry and gurindam to enrich the knowledge of student understanding. Expert comments on the second material, namely the construction of writing adapted to the characteristics of learning, add interesting illustrations according to the substance of the picture, the menu must be a conference of learning elements, and supplemented with instructional media.

Based on the results of the assessment given to the design expert, the next step is to validate the product development. This validation is carried out by design experts who are competent in their fields. The selected experts were lecturers of Basic Education namely Dr. Daulat Saragi, M.Hum and German lecturer Dr. Surya Masniari Hutahalung, M.Hum.

The descriptions of the analysis of the validation expert provided by the learning design expert based on the above table are:

1. The initial design of interactive multimedia Adobe Flash CS5 scored 50 with a percentage of $89.2 \%$ and Good assessment criteria. This is because the initial design includes the appearance of the layout elements on the front background already and the behind is neat.

2. Design content on interactive multimedia Adobe Flash CS5 gets a score of 51 with a percentage of $91 \%$ and Very Good criteria. The validator suggests adjusting back sound with learning media.

3. Interactive multimedia typography adobe flash CS5 gets a score of 21 with a percentage. 87.5\% and the Good Assessor criteria. Typography design is suitable for the use of variations of letters, (bold, Italic, for the title comic sans ms.)

4. Illustration of adobe flash interactive multimedia content CS5 gets a score of 21 with a percentage of $87.5 \%$ and Good assessment criteria. Module design has been considered creative and dynamic, able to express the meaning of objects and shapes accurately, and proportionally.

Based on the feasibility criteria of the learning design product above, the score obtained on the learning design validation obtained an average score of $88.8 \%$ on the Good criteria. These criteria indicate that learning design products in the resulting development are worth testing out in the learning process. 
Commensurate with Astriana's research (2017) in his journal "Development of Folk Poetry Learning Media Based on Macromedia Flash in Students Class VII SMP Negeri 18 Medan Academic Year 2017/2018" Based on the feasibility criteria of learning design products, the scores obtained on the validation of learning designs scored an average of $94 \%$ in the very feasible category.

Validation is also given to material experts to see the feasibility of the material in accordance with the development of designed interactive multimedia. The results of the validation of the material against aspects of teaching material obtained.

Validation analysis provided by the material experts is:

1. The feasibility of the content which includes the suitability and depth of the concept with K13, material accuracy, supporting material scores 74 with a percentage of $84 \%$ and Good criteria.

2. The feasibility of the presentation which includes the technique of presentation, presentation of learning, and completeness of the presentation received a score of 88 with a percentage of $91.6 \%$ and Very Good criteria.

3. The aspect of interactive multimedia that includes media assessments, language effectiveness, graphic determinations, image resolutions score 42 with a percentage of $87.5 \%$ and Good criteria.

4. The aspects of language assessment include the determination of the use of language, spelling determination, conformity to the level of development of students, wrinkling and integration of the flow of thought, and the use of terms, figure and symbols scored 69 with a percentage of $82.5 \%$ and criteria good.

\section{Conclusion}

Based on the feasibility criteria of the learning material products above, the score obtained on the validation of the learning material obtained an average score of $86.4 \%$ on the Good criteria. This criterion shows that learning material products in the resulting development deserve to be tested in the learning process.

Commensurate with Astriana's research (2017) in her journal "Development of Folk Poetry Learning Media Based on Macromedia Flash in Students Class VII SMP Negeri 18 Medan Academic Year 2017/2018". Based on the feasibility criteria of learning design products, the scores obtained on the validation of material experts learning gained an average value of $92 \%$ included in the very feasible category.

Overall the validation of the material and the validation of the design expert are worth testing. The results of this study are in line with Amrulloh (2013) in his journal "The theoretical feasibility of interactive multimedia learning media for mutation material for high schools"

The feasibility of the media and material scored an average of $88.8 \%$ with the criteria of "good" and $86.4 \%$ with the criteria of "good" in the development of interactive multimedia on Folk Poetry Text Learning.

\section{References}

Ahmad, M. (2014). Cara Aktif Membuat CD Interaktif. Jakarta: Elex Media Komputindo Aji, T.,A. (2010). Analisis dan perancangan sistem informasi produk berbasismultimedia dinamis. Jurnal Dasi Vol. 11 No. 1 
Budapest International Research and Critics in Linguistics and Education (BirLE) Journal Volume 2, No 4, November 2019, Page: 259-271 e-ISSN: 2655-1470 (Online), p-ISSN: 2655-2647 (Print) www.bircu-journal.com/index.php/birle emails: birle.journal@gmail.com birle.journal.qa@gmail.com

Amrulloh, R, et al. (2013). Kelayakan Teoritis Media Pembelajaran Multimedia Interaktif Materi Mutasi untuk SMA. Jurnal Berkala Ilmiah Pendikan Bilogi. Vol.2 No 2

Anas, S. (2008). Pengantar Evaluasi Pendidikan. Jakarta: Raja Grafindo Persada.

Ariani, N., and Haryanto, D. (2010). Pembelajaran Multimedia di Sekolah. Jakarta: Prestasi Pustaka. Arsyad,

Azhar. (2014). Media Pembelajaran. Jakarta: Rajawali Press

Arda, et al. (2015). Pengembangan Media Pembelajaran Interaktif Berbasis Komputer untuk siswa SMP kelas. VIII. Vol.3. No.1

Arikunto, S. (2013). Dasar-Dasar Evaluasi Pendidikan. Jakarta: Bumi Aksara

Astriana. (2018). Development of Folk Poetry Learning Media Based on Macromedia Flash in to Students Class VII SMP Negeri 18 Medan Academic Year 2017/2018. Thesis: Education Language and Sastra Indonesia. Master Student at State University of Medan.

Badan Standar Nasional Pendidikan (BSNP). (2006). Panduan Penyusunan Kurikulum

Borg, W. R. \& Gall, M. D. (1983). Educational research: an introduction (4 ${ }^{\text {th }}$ ed). New York: Longman.

Cahyanto, Z.,D. (2008). Pengembangan Media Pembelajaran Menulis Puisi Untuk Siswa Kelas VIII Berbasis Multimedia Interaktif. Jurnal Online.

Dalman. (2014). Keterampilan menulis. Jakarta : raja Grafindo Persada

Damayanti, D. (2013). Buku Pintar Sastra Indonesia. Yogyakarta: Araska.

Danandjaja, J. (2007). Foklor Indonesia: Ilmu gossip, dongeng, dan lain-lain. Jakarta: Pustaka Utama Grafiti.

Darmawan, D. (2014). Inovasi pendidikan: pendekatan praktik teknologi multimedia dan pembelajaran online. Bandung: PT Remaja Rosdakarya.

Daryanto. (2005). Belajar Computer Animasi Macromedia flash. Bandung : Yrama Widya

Daryanto. (2013). Media Pembelajaran: Peranannya Sangat Penting Dalam Mencapai Tujuan Pembelajaran.Yogyakarta: Gava Media

Dedy, I. (2012). “Cara Cepat Belajar Adobe Flash”. Dokumen Ilmu Komputer.Com komunitas eLearning.

Dedy, I. (2012). “Cara Cepat Belajar Adobe Flash”. Dokumen Ilmu Komputer.Com komunitas eLearning

Drabenstott, K.M. (2003). Interactive multimedia for library-user education. Portal Libraries and the Academy. Baltimore Vol. 3, Iss. 4.

Effendy, T. (2004). Pemakaian Ungkapan dalam Upacara Perkawinan orang Melayu, Balai Kajian dan Pengembangan Budaya Melayu bekerja sama dengan Adi Cita. Yogyakarta

Haris, W. (2015). Bentuk dan makna tuturan kabhanti manari pada masyarakat muna. Jurnal humanika no. 15, vol. 3

Henra, K. (2015). Bentuk Dan Makna Nyanyian Rakyat Muna Berdasarkan Status Sosial. Skripsi

Kemendikbud. (2017). Bahasa Indonesia.Jakarta

Kosasih, E. (2016). Jenis-Jenis Teks. Bandung: Yrama Widya.

Munadi, Y. (2013). Media Pembelajaran: Sebuah Pendekatan Baru. Jakarta Referensi

Munir. (2012). Multimedia Konsep \& Aplikasi dalam Pendidikan. Bandung: Alfabeta

Musfiqon, HM. (2012). Pengembangan Media dan Sumber Pembelajaran. Jakarta: Prestasi Pustaka

Nirma, Y. (2018). Pengaruh Penggunaan Media Gambar Terhadap Kemampuan Menulis Puisi Rakyat Siswa Kelas VII SMP Negeri 6 Kota Jambi Tahun Ajaran 2017/2018. aksara: Jurnal Ilmiah Pendidikan Bahasa dan Sastra Indonesia Vol. 2 No. 2 September. 
Damayanti, D. (2013). Buku Pintar Sastra Indonesia. Yogyakarta: Araska.

Pradopo, R., D. (2002). Pengkajian Puisi. Yogyakarta: Gadjah Mada University Press.

Qhurniawan, D.,A. (2016). Pengembangan Multimedia Pembelajaran Interakti Menulis Teks Eksplanasi Berdasarkan Pendekatan Proses Untuk Siswa Smp Kelas VII. Skripsi

Rahmawati, D. (2010). "Pokok-Pokok Ajaran Islam Dalam Novel Ketika Cinta Bertasbih Karya Habibburahman El Shirazy: Tinjauan Sosiologi Sastra”. Skripsi. Surakarta: Fakultas Ilmu Pendidikan. Universitas Muhammadiyah Surakarta.

Ratnasari, A. (2016). Pengembangan media pembelajaran interaktif keselamatan dan kesehatan kerja (k3) pada program studi ketenagalistikan di sekolah menengah kejuruan. Program studi pendidikan teknik mekatronika : E-Journal Universitas Negeri Yogyakarta http://journal.student.uny.ac.id/ojs

Rita and Julaga Situmorang. (2014). Pengembangan Pembelajaran Multimedia Interaktif Berbasis Internet Pelajaran Bahasa Inggris. PPS Universitas Negeri Medan. Jurnal teknologi informasi \& Komunikasi dalam pendidikan. Vol 4. No.

Reni, Y. (2017). Pengembangan Multimedia Adobe Flash Cs5 Berbasis Stad Sebagai Media Pembelajaran Ipa Pada Pokok Bahasan Sistem Gerak Pada Manusia Untuk SMP/MTs. Skripsi

Rusman. (2013). Belajar dan Pembelajaran Berbasis Komputer: Mengembangkan Profesionalisme Guru Abad 21. Bandung: Alfabeta

Hackbarth, S. (1996). The Educational Technology Handbook. Englewood Cliffs. New Jersey: Educational Technology Publications Inc.

Samsuyurnita. (2012). Keterampilan Menulis. Medan. Umsu

Sanjaya, Wina. 2010. Strategi Pembelajaran Berorientasi Standar Proses Pendidikan. Jakarta: Prenada Media Group.

Sanaky, AH. (2013). Media Pembelajaran Interaktif-inovatif. Yogyakarta: Kaukuba Dipantara

Soebachman, A. (2014). 4 Hari Mahir Menulis Artikel, Cerpen, Novel, Skripsi. Yogyakarta: Syura Media Utama.

Sucipto. (2010). Penulisan Naskah Pembelajaran Multimedia Interaktif Berbantuan Komputer (Multimedia). Makalah. Yogyakarta: Balai Teknologi Komunikasi Pendidikan (BTKP)

Sugiyono. (2012). Metode Penelitian Pendidikan Pendekatan Kualitatif Kuantitatif, dan R\&D. Bandung : Alfabeta

Suryanto, A., and Haryanto, A. (2007). Panduan Belajar Bahasa dan Sastra Indonesia untuk SMA dan MA Kelas X. Tangerang: ESIS. Sukiman. 2017. Pengembangan Modul Puisi Rakyat Sumbawa Sebagai Bahan Pembelajaran Sastra Di SMP. Jurnal

Susilana, R., and Riyani, A. (2007). Media Pembelajaran. Bandung: CV Wacana Prima.

Susilo, O., S. (2017). Pengembangan multimedia interaktif ipa kelas v sd pokok bahasan organ tubuh manusia dan hewan. Jurnal Edcomtech Volume 2, Nomor 2

Swajati, G. W. (2005). Membuat CD Multimedia Interaktif untuk Bahan Ajar ELearning. Jakarta: PT Elex Media Komputindo.

Syaodih, N. (2015). Pengembanagan Bahan Ajar Bahasa dan Sastra Indonesia. Medan: IKAPI Tomlinson, B. (2011). Materials Development in Language Teaching. Cambridge. University Press Vaughan, T. (2006). Multimedia: making it work. (Translated by Theresia Arie Prabawati \& Agnes Heni Triyuliana). Yogyakarya: Andi.

Yunita, R. (2017). Pengembangan Multimedia Adobe Flash Cs5 Berbasis Stad Sebagai Media Pembelajaran IPA Pada Pokok Bahasan Sistem Gerak Pada Manusia Untuk Smp/Mts. Skripsi 